\title{
L-Arginine Modulates Maternal Hormonal Profiles and Neonatal Traits during Two Stages of Pregnancy in Sheep
}

\author{
Moustafa Zeitoun ${ }^{*}$, Ahmed Al-Ghoneim² ${ }^{2}$, Khaled Al-Sobayil' ${ }^{1}$, Suliman Al-Dobaib ${ }^{1}$ \\ ${ }^{1}$ Department of Animal Production and Breeding, College of Agriculture and Veterinary Medicine, Qassim \\ University, Al-Qassim, KSA \\ ${ }^{2}$ Ministry of Agriculture, Riyadh, KSA \\ Email: *mmzeitoun@yahoo.com
}

Received 19 December 2015; accepted 26 February 2016; published 29 February 2016

Copyright (C) 2016 by authors and Scientific Research Publishing Inc.

This work is licensed under the Creative Commons Attribution International License (CC BY).

http://creativecommons.org/licenses/by/4.0/

(c) (i) Open Access

\section{Abstract}

A $2 \times 2$ factorial arrangement was designed to test effects of supplementation of a low (L, $75 \mathrm{mg} / \mathrm{kg}$ BW) vs. high (H, $150 \mathrm{mg} / \mathrm{kg} \mathrm{BW}$ ) L-arginine given at early (first 56 days) vs. late (last 56 days) pregnancy on maternal hormones and neonatal traits. Thirty Najdi pregnant ewes were randomly allocated into 6 groups. Ewes in G1 and G2 served as controls (C), given $50 \mathrm{ml}$ saline at either early (CE) or late (CL) pregnancy, respectively. G3 and G4 ewes in early pregnancy received low (LE) and high L-arginine (HE), respectively. G5 and G6 ewes in late pregnancy received low (LL) and high (HL) L-arginine, respectively. A weekly blood sample was collected from initiation of the treatment till parturition. Serum growth hormone (GH), insulin-like growth factor-I (IGF-I), insulin, progesterone (P4) and estradiol $17 \beta(\mathrm{E} 2)$ profiles were determined. Neonatal traits were also determined. Insulin was higher $(\mathrm{P}<\mathbf{0 . 0 5})$ in low arginine compared with control and high dosage. HL ewes (G6) exhibited increased ( $P<0.05$ ) IGF-I and decreased plasma E2. IGF-I increased and GH decreased at late pregnancy. The increase $(P<0.05)$ in plasma $P 4$ between early and late pregnancy was slightly $(P<0.10)$ affected by $L$-arginine dosage. Low arginine increased $(P<0.05)$ birth weight by about $35 \%(4.86 \mathrm{~kg})$ over the control $(3.58 \mathrm{~kg})$; whereas high arginine tended to increase birth weight $(4.31 \mathrm{~kg}, \mathrm{P}>0.05)$. Lamb survival rates at birth in LE ewes were highest $(100 \%)$ compared to other treatments. In conclusion, supplementing pregnant ewes with low dosage of L-arginine at early stage of gestation increased lamb birth weight and survival, and improved maternal health.

\section{Keywords}

L-Arginine, Najdi Ewes, Gestation, Hormones, Neonate

${ }^{*}$ Corresponding author.

How to cite this paper: Zeitoun, M., Al-Ghoneim, A., Al-Sobayil, K. and Al-Dobaib, S. (2016) L-Arginine Modulates Maternal Hormonal Profiles and Neonatal Traits during Two Stages of Pregnancy in Sheep. Open Journal of Animal Sciences, 6, 95-104. http://dx.doi.org/10.4236/ojas.2016.62012 


\section{Introduction}

Due to their prolificacy, it is well known that pregnant ewes require more nutrients during pregnancy term for the sake of fetal growth and development. Whether these nutrients are needed in the early or late pregnancy is a subject of controversy. Recently, evidence has emerged that the amino acid L-arginine (Arg) showed anabolic merit within the body via its mediator nitrous oxide (NO). NO is a product derived from the catalysis of the enzyme, nitric oxide synthase, of the oxidation of L-arginine into L-citrulline. Also, NO is considered an endothelium-derived relaxing factor essential for increasing systemic vasodilatation [1]-[3]. It has been found that dietary supplementation of L-arginine increased NO synthesis in various tissues within physiological ranges [4], normalized plasma glucose levels in streptozotocin-induced diabetic rats [5] and attenuated hyperglycemia in ZDF rats [6]. There is compelling evidence that L-arginine regulates inter-organ metabolism of energy substrates and the function of multiple organs [7]. Experimental and clinical studies indicated that L-arginine is a nutritionally essential amino acid for spermatogenesis, embryonic survival, fetal and neonatal growth, as well as maintenance of vascular tone and hemodynamic [8]-[10]. Moreover, there are indications that dietary supplementation or intravenous administration of L-arginine is effective in improving functions of reproduction, cardiovascularity, pulmonary system, renal filtration, gastrointestinal, liver and immunity, as well as facilitating wound healing, enhancing insulin sensitivity and maintaining tissue integrity [7]. Arginine was found to enhance embryonic implantation and development in rats [11], sheep [12] and pigs [13]. Multiple births of local sheep ewes with a high percent of mortality at birth necessitate to find a source of nutrients that support fetal wellbeing. Recently, Mateo et al. [13] reported that supplementing arginine to the gestation diet for gilts increased the number and litter weight of live-born piglets by $22 \%$ and $24 \%$, respectively. Therefore, this study aimed at monitoring the optimum dosage of L-arginine, and the proper gestation stage which maximizes the ewe's hormonal profile during pregnancy and subsequently enhances the neonatal survival and birth weight.

\section{Material and Methods}

\subsection{Animals, Location and Treatment}

The experiment was carried out in the Animal Production Research Unit at the University of Qassim Agricultural Experimental Station. Thirty adult Najdi ewes (16 \pm 2 month age; $50 \pm 3 \mathrm{~kg} \mathrm{B.W})$ were equally and randomly allotted into six treatments $(\mathrm{n}=5$ ewes/group, Figure 1). Animals were lodged in semi-shaded pens and offered $300 \mathrm{~g}$ barley daily as a concentrate in addition to alfalfa hay $A d$ lib according to NRC [14]. Clean tap water and equilibrated salt formula as licks were freely accessible.

\subsection{Arginine-HCl}

L-arginine-HCl was purchased from Nutrients Scientific (Diamond Bar, CA, USA) in crystalline powder with 99.6\% purity. The formula was prepared in two forms; one contained $75 \mathrm{mg} \mathrm{L}$-arginine/ml (Formula 1; produces $75 \mathrm{mg} / \mathrm{kg} / \mathrm{head} / \mathrm{day}$ ) and the second contained $150 \mathrm{mg}$ L-arginine $/ \mathrm{ml}$ (Formula 2; produces $150 \mathrm{mg} / \mathrm{kg} / \mathrm{head} / \mathrm{day}$ ). Each of the arginine-treated animals was given an oral dose $(50 \mathrm{ml} /$ day $)$ of the designed formula for the duration of the treatment (56 days, Figure 1).

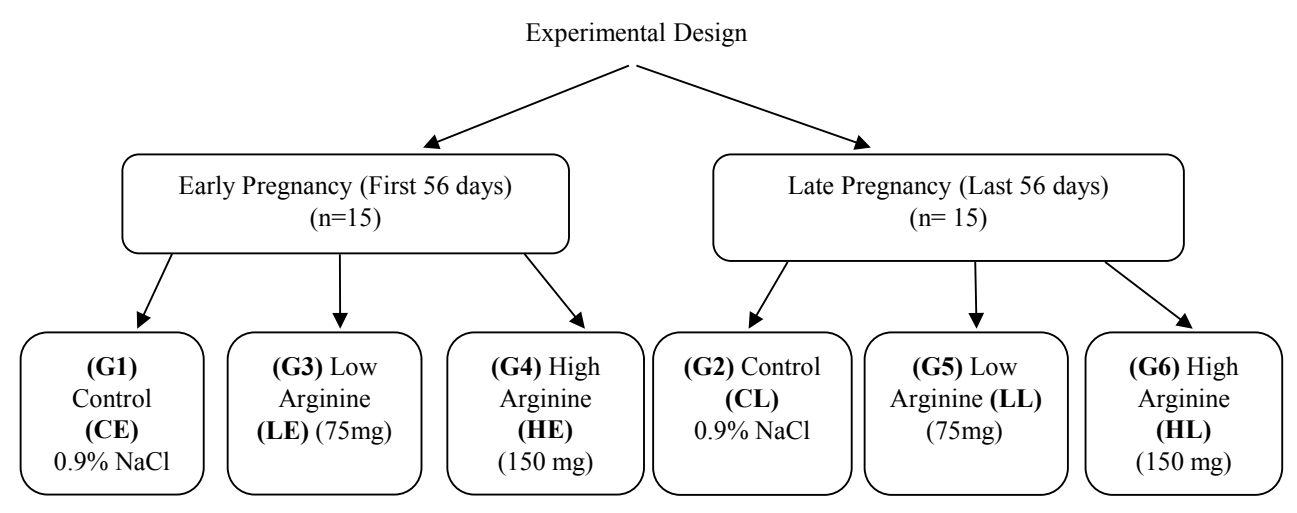

Figure 1. Experimental outline. 


\subsection{Experimental Design}

As illustrated in Figure 1, the design based on 2 factors; i.e., stage of pregnancy and dosage of L-arginine. Therefore, 6 groups $(\mathrm{G})$ of ewes $(\mathrm{n}=5 / \mathrm{G})$ were designed as follow; $\mathrm{G} 1$ and $\mathrm{G} 2$ ewes received daily oral dose of $50 \mathrm{ml} 0.9 \% \mathrm{NaCl}$ (physiological saline) for 56 days, G3 and G5 ewes were orally given $50 \mathrm{ml}$ of the low L-arginine ( $75 \mathrm{mg} / \mathrm{kg} \mathrm{B.W/day)} \mathrm{for} 56$ days and G4 and G6 ewes were orally given $50 \mathrm{ml}$ of high L-arginine $(150 \mathrm{mg} / \mathrm{kg} \mathrm{B} . \mathrm{W} /$ day) for 56 days. At the beginning of the treatment, G1, G3 and G4 were at an early gestation; however G2, G5 and G6 were at late gestation.

\subsection{Blood Sampling}

A jugular venipuncture was used to collect a whole blood sample in EDTA-containing Vacutainer ${ }^{\circledR}$ tube. Blood sample collection commenced just before the treatment $(\mathrm{d}=0)$ and continued every week until parturition in late pregnant ewes. However, in early pregnant ewes blood samples were collected every week for 8 consecutive weeks just after initiation of the treatment and once a month thereafter up till parturition. At the time of parturition a blood sample was collected out of all mothers.

\subsection{Hormone Determinations}

\subsubsection{Insulin Determination}

Insulin concentration in plasma was determined according to the method of Clark and Hales [15] by a commercial specific ovine ELISA kit (CusaBio, Wuhan, China). Intra-assay coefficient of variation was 3.9\%.

\subsubsection{IGF-I Determination}

The determination of IGF-I was accomplished by a commercial ELISA specific kit for sheep (CusaBio, Wuhan, China) using the method described by Breier et al. [16]. Intra-assay coefficient of variation was $5.3 \%$.

\subsubsection{GH Determination}

GH determination was done by a commercial sheep specific ELISA kit (Blue Gene Biotech Co., Shanghai, China) according to the method described by Reiter et al. [17]. Intra-assay coefficient of variation was $4.7 \%$.

\subsubsection{Progesterone $\left(\mathrm{P}_{4}\right)$ Determination}

Plasma progesterone was quantified by the use of a commercial ELISA kit (HUMAN, Germany) according to Joyce et al. [18]. Intra-assay coefficient of variation was $6.3 \%$.

\subsubsection{Estradiol $17 \beta\left(\mathrm{E}_{2}\right)$ Determination}

Plasma estradiol-17 $\beta$ was quantified by the use of a commercial ELISA kit (HUMAN, Germany) according to Abuknesha and Exley [19]. Intra-assay coefficient of variation was 9.4\%.

\subsection{Neonatal Birth Weight and Survival}

Offspring were weighed at birth and at weaning (day 70) using a scale balance. Also percentage of survival at birth and weaning were recorded within each treatment.

\subsection{Statistical Analyses}

Data of hormone concentrations were analyzed by the least square analysis of variances for repeated measures by SAS [20]. The 2-way analysis of variances was applied using the following model.

$$
\mathrm{Y}_{\mathrm{ijk}}=\mu+\mathrm{S}_{\mathrm{i}}+\mathrm{D}_{\mathrm{j}}+\mathrm{S}_{\mathrm{i}} \mathrm{D}_{\mathrm{j}}+\mathrm{e}_{\mathrm{ijk}}
$$

where:

$\mathrm{Y}_{\mathrm{ijk}}=$ an observation taken on the $\mathrm{k}^{\text {th }}$ ew;

$\mu=$ overall mean;

$\mathrm{S}_{\mathrm{i}}=$ a fixed effect of the $\mathrm{i}^{\text {th }}$ stage of pregnancy ( $\mathrm{i}=2$ stages);

$D_{j}=$ a fixed effect of the $j^{\text {th }}$ dosage of L-arginine $(j=3$ dosages $)$;

$\mathrm{e}_{\mathrm{ij}}=$ Random error assumed to be independent and normally distributed;

with mean $=0$ and variance $=\sigma^{2}$ e. 
However, data for neonatal parameters and survival were analyzed by the general linear model-least square analysis of variance. Mean comparisons between treatments were achieved by the Duncan's Multiple Range Test [21]. Significance level was considered at $\mathrm{P}<0.05$.

\section{Results}

As sown in Table 1, the survival of offspring at birth was $100 \%$ in all treatments except when the high dose of L-arginine was given at late pregnancy (83.3\%). The treatment has nothing to affect the litter size. The high arginine resulted mean of $1.35 \mathrm{lamb} /$ ewe which is similar to the control (1.32) and higher than L ewes (1.0). Survival of lambs at weaning was similar to control $(100 \%)$ only in the case of low arginine given at early pregnancy, however other treatments reduced percent of survival at weaning $(66.7 \%, 50 \%$ and $83.3 \%$ in low-late, high-early and high-late ewes, respectively). Total live weight $(\mathrm{kg})$ of lambs per treatment was found in ewes given the low dose at early pregnancy $(94.5 \mathrm{~kg})$. Therefore, mean lamb weight at weaning was slightly heavier in the ewes given low arginine at early pregnancy $(18.9 \mathrm{~kg})$ than control. However, the lightest lamb weight was found in ewes given low arginine at late pregnancy $(10.42 \mathrm{~kg})$ and in ewes given high arginine at early pregnancy $(11.96 \mathrm{~kg})$. Dose of L-arginine (Figure 2) revealed a significant $(\mathrm{P}<0.05)$ increase in birth weight at low $(4.86 \mathrm{~kg})$ than control $(3.58 \mathrm{~kg})$, however at high arginine the birth weight $(4.31 \mathrm{~kg})$ tended to be higher than control. Irrespective of the dose of L-arginine, administration of L-arginine at early stage of pregnancy (Figure $3)$ significantly $(\mathrm{P}<0.05)$ increased lamb birth weight $(4.52 \mathrm{~kg})$ compared with late pregnancy $(3.79 \mathrm{~kg})$.

Similar trend was found in lamb weaning weight (Figure 4). The lambs born of ewes given low dose of arginine were heavier $(\mathrm{P}<0.05)$ than control and these born of ewes given high arginine $(13.51,17.61$ and $16.11 \mathrm{~kg}$ for $\mathrm{C}, \mathrm{L}$ and $\mathrm{H}$, respectively).

Table 1. Effect of dosage of L-Arginine $\times$ stage of pregnancy on maternal and neonatal traits of Najdi ewes.

\begin{tabular}{|c|c|c|c|c|c|c|}
\hline \multirow{2}{*}{ Trait } & \multicolumn{2}{|c|}{ Control } & \multicolumn{2}{|c|}{ Low } & \multicolumn{2}{|c|}{ High } \\
\hline & Early & Late & Early & Late & Early & Late \\
\hline Lamb survival at birth (\%) & 100 & 100 & 100 & 100 & 100 & 83.3 \\
\hline Litter size & 1.25 & 1.4 & 1.0 & 1.0 & 1.5 & 1.2 \\
\hline Ewe's survival (\%) & 80 & 100 & 100 & 60 & 80 & 100 \\
\hline Lamb birth weight $(\mathrm{kg})$ & 3.76 & 3.44 & 4.99 & 4.63 & 4.76 & 3.76 \\
\hline Lamb crop/ewe at birth $(\mathrm{kg})$ & 4.7 & 4.8 & 4.99 & 4.63 & 7.14 & 4.51 \\
\hline Lamb weaning weight (kg) & 13.84 & 13.27 & 18.9 & 15.63 & 15.95 & 16.21 \\
\hline Lamb survival at weaning (\%) & 100 & 100 & 100 & 66.7 & 50 & 83.3 \\
\hline
\end{tabular}

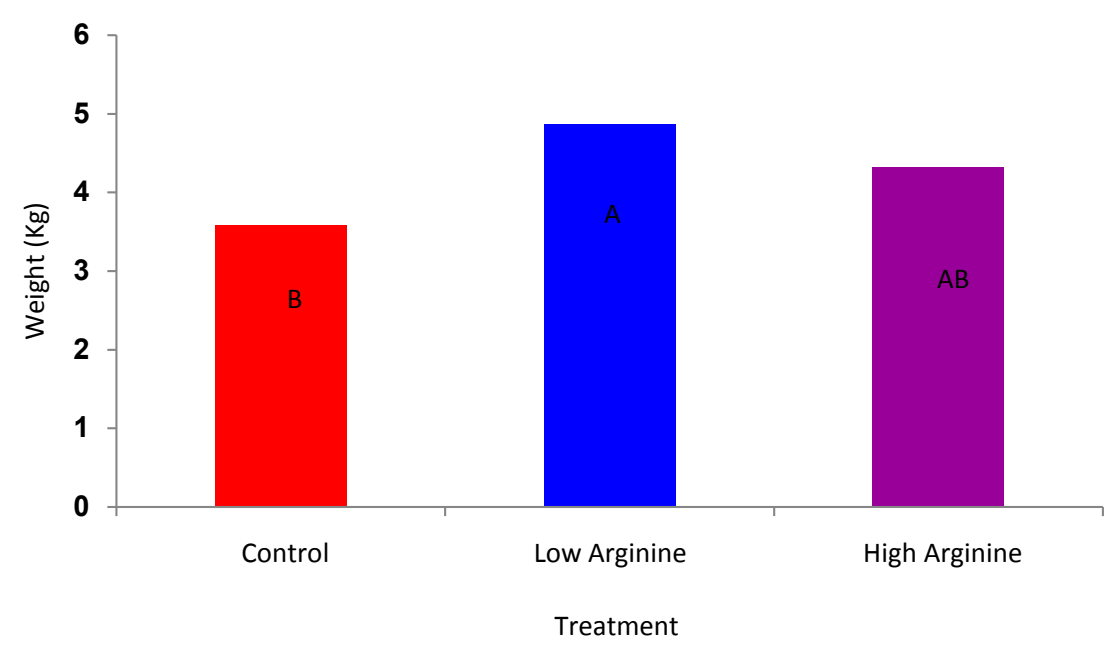

Figure 2. Effect of dosage of L-arginine on ewe's neonatal birth weight $(\mathrm{P}<0.05)$. 


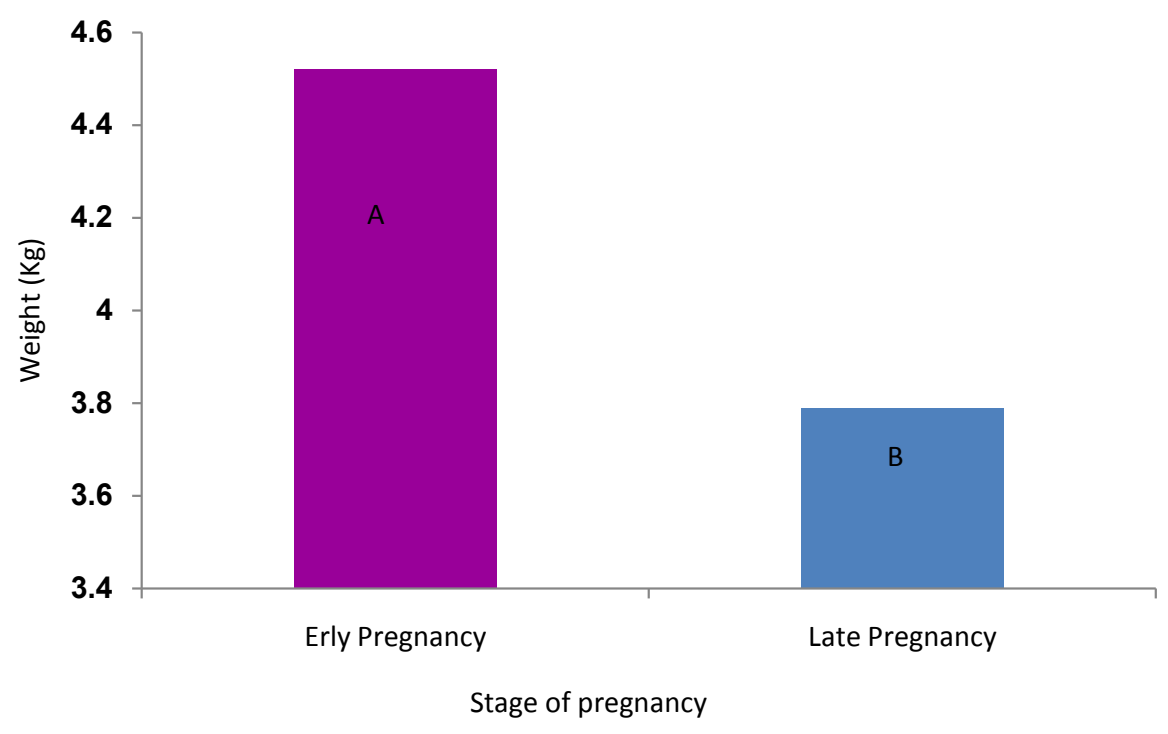

Figure 3. Effect of stage of pregnancy at which L-arginine was given on ewe's neonatal birth weight $(\mathrm{P}<0.05)$.

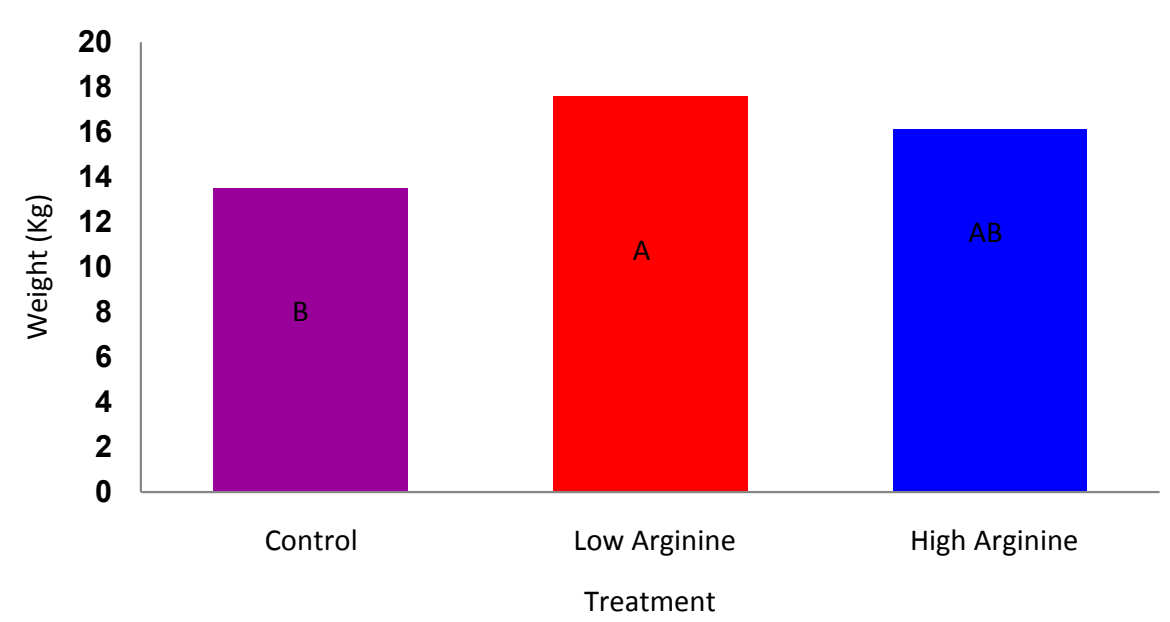

Figure 4. Effect of dosage of L-arginine on ewe's neonatal weaning weight $(\mathrm{P}<0.05)$.

Administering the high dose of L-arginine at early pregnancy reulted in the highest mortality of lambs after birth (50\% survival), however administering the low dose of arginine at early pregnancy maintained the highest lamb survival after birth (100\%) which was similar to control lambs (Figure 5). Either low or high arginine at late pregnancy decreased the survival rate by $16.7 \%-33.3 \%$ than control.

As illustrated in Figure 6, the low arginine increased insulin secretion. The increase was obvious at late more than at early pregnancy (Table 2). Contrariwise, IGF-I decreased $(\mathrm{P}<0.05)$ at low and increased $(\mathrm{P}<0.05)$ at high arginine compared with control. The low dose either given at early or late pregnancy maintained IGF-I at the lowest levels. In control ewes the normal trend of IGF-I revealed an increase towards the late stage of pregnancy, whereas giving high dose of arginine at late pregnancy caused significant $(\mathrm{P}<0.05)$ elevation in IGF-I (Table 2).

Growth hormone $(\mathrm{GH})$ decreased $(\mathrm{P}<0.05)$ as pregnancy progressed in control ewes. This was the case in $\mathrm{H}$-ewes, whereas in L-ewes the GH levels remained in its initial values during both stages of pregnancy.

Administration of L-arginine at early $(\mathrm{L}$ and $\mathrm{H})$ decreased estradiol $17 \beta$, however at late pregnancy, there obtained an opposite trend as the low arginine maintained high levels of E2 but the high arginine reduced E2 levels. Giving either dose of arginine at early pregnancy decreased $(\mathrm{P}<0.05)$ progesterone levels, whereas arginine restored the $\mathrm{P} 4$ levels to the normal when given at late pregnancy. 


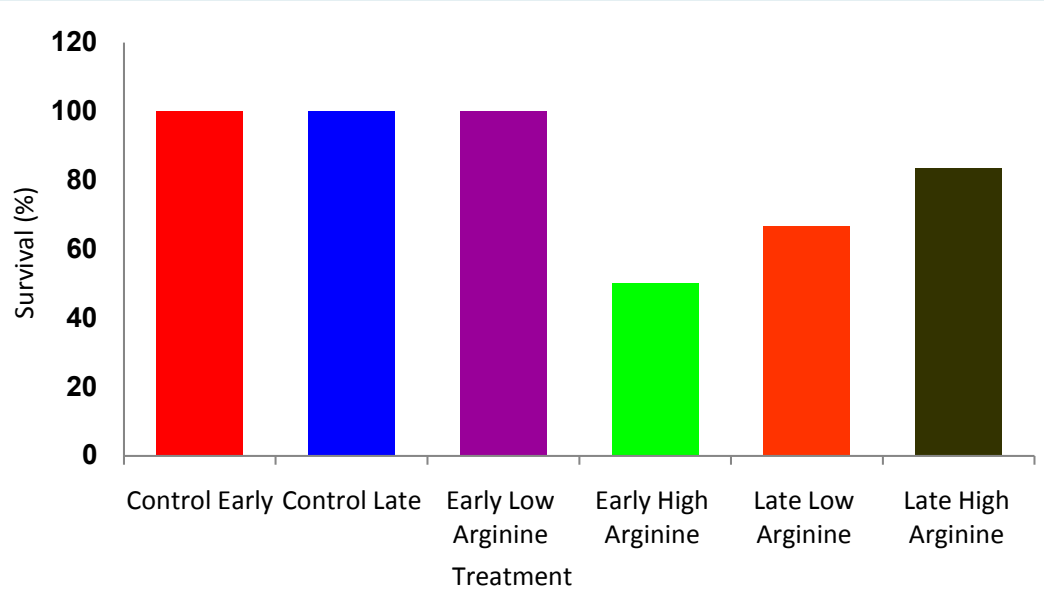

Figure 5. Effect of L-arginine dosage $\times$ stage of pregnancy on neonatal survival at weaning.

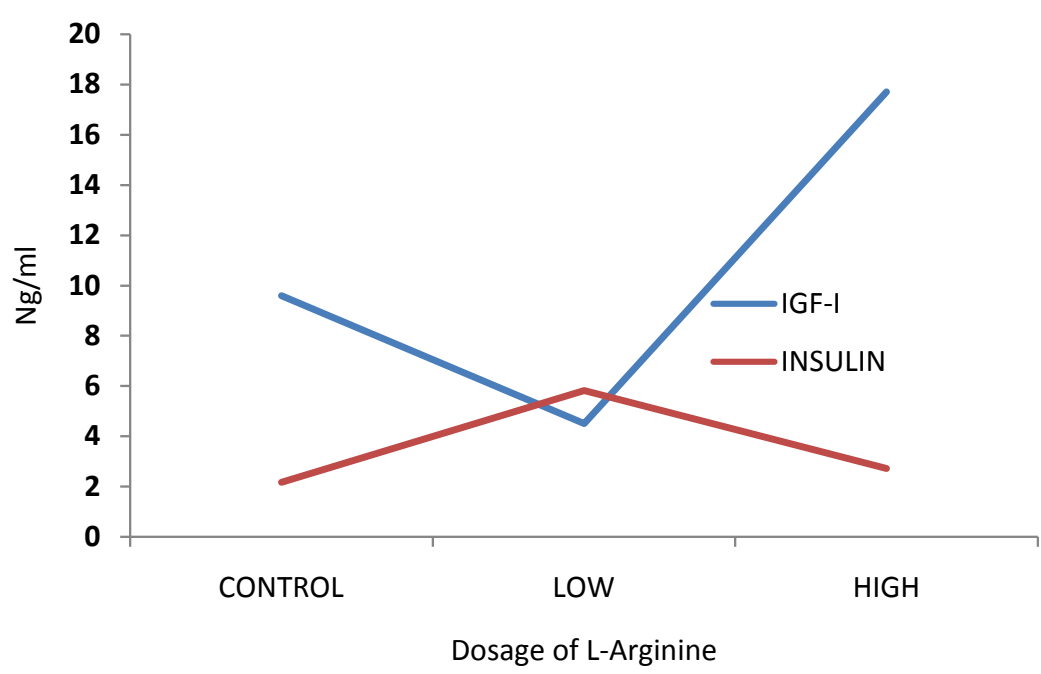

Figure 6. Effect of dosage of L-Arginine on pregnant ewe plasma insulin and IGF-I.

Table 2. Effect of dosage of L-Arginine $\times$ stage of pregnancy on maternal hormone concentration of Najdi ewes (Mean \pm SEM).

\begin{tabular}{ccccccc}
\hline Hormone & Control & & Low & & High \\
\hline & Early & Late & Early & Late & Early \\
Insulin $(\mathrm{ng} / \mathrm{ml})$ & $4.0 \pm 0.44^{\mathrm{ab}}$ & $0.32 \pm 0.07^{\mathrm{c}}$ & $6.10 \pm 1.46^{\mathrm{a}}$ & $5.50 \pm 1.57^{\mathrm{ab}}$ & $2.0 \pm 0.65^{\mathrm{bc}}$ & $3.34 \pm 1.08^{\mathrm{abc}}$ \\
IGF-I $(\mathrm{ng} / \mathrm{ml})$ & $5.85 \pm 2.94^{\mathrm{a}}$ & $13.33 \pm 3.76^{\mathrm{b}}$ & $4.62 \pm 0.43^{\mathrm{a}}$ & $4.36 \pm 0.59^{\mathrm{a}}$ & $5.91 \pm 0.58^{\mathrm{a}}$ & $28.19 \pm 6.15^{\mathrm{c}}$ \\
GH $(\mathrm{ng} / \mathrm{ml})$ & $2.28 \pm 0.10^{\mathrm{a}}$ & $1.54 \pm 0.06^{\mathrm{c}}$ & $1.99 \pm 0.17^{\mathrm{ab}}$ & $1.95 \pm 0.14^{\mathrm{abc}}$ & $2.14 \pm 0.13^{\mathrm{a}}$ & $1.67 \pm 0.11^{\mathrm{bc}}$ \\
$\mathrm{E}^{*}(\mathrm{pg} / \mathrm{ml})$ & $82.20 \pm 11.02^{\mathrm{a}}$ & $70.24 \pm 5.6^{\mathrm{ab}}$ & $58.74 \pm 15.04^{\mathrm{bc}}$ & $81.38 \pm 5.87^{\mathrm{a}}$ & $62.77 \pm 6.71^{\mathrm{ab}}$ & $36.48 \pm 7.34^{\mathrm{c}}$ \\
$\mathrm{P}^{* *}(\mathrm{ng} / \mathrm{ml})$ & $12.53 \pm 0.93^{\mathrm{a}}$ & $11.37 \pm 1.0^{\mathrm{a}}$ & $8.28 \pm 1.13^{\mathrm{b}}$ & $12.86 \pm 0.99^{\mathrm{a}}$ & $8.60 \pm 1.00^{\mathrm{b}}$ & $10.61 \pm 0.95^{\mathrm{a}}$ \\
\hline
\end{tabular}

${ }^{*} \mathrm{E} 2=$ Estradiol $17 \beta,{ }^{* *} \mathrm{P} 4=$ Progesterone. ${ }^{\mathrm{a}, \mathrm{b}, \mathrm{c}}$ Means in the same row with different superscript significantly differ $(\mathrm{P}<0.05)$.

\section{Discussion and Conclusions}

Last decades the animal scientists focused and are still focusing on the roles played by some critical nutrients during the fetal growth and development. Of these nutrients, there were some of essential and semi-es- sential amino acids, especially L-arginine, methionine and citrolline. L-arginine is considered a semi-essential amino 
acid because the body normally produces it in sufficient amounts. However, supplementation may be needed in special conditions such as malnutrition [22]. Therefore, L-arginine is considered a nutritionally essential amino acid in case of gestating mammals [7]. In domestic animals as well as human most of early embryonic losses occur during the peri-implantation period [23] [24]. Furthermore, intrauterine growth retardation (IUGR), which increases the risk for neonatal mortality and morbidity and compromises postnatal growth and health, is a significant problem in humans and other mammals [25]. Percent of loss during pregnancy in livestock species ranges between $20 \%$ and $50 \%$ [24]. Sheep is considered a demandable source of palatable meat to the people in the Middle Eastern countries. Due to the harsh climate in which the sheep herds are raised, a high percent of pregnancy failure impeded the success of raising this animal. The increase of ambient temperature, lack of forages and concentrates and frequency of sand storms that attacks the sheep herds raised in the desert of the central region of Saudi Arabia has motivated the research on finding alternatives to overcome these challenges. The pre-implantation embryo is susceptible to maternal heat stress but the susceptibility declines as development proceeds [26]. Embryonic loss is increased when the dam is exposed to one or more of the many stresses [27]. Stress has a deleterious effect on reproductive efficiency in animals [28]. Stressors (e.g. transport) affect the reproductive function via actions at the hypothalamic level $(\mathrm{GnRH})$ or at the ovarian level (P4) [29]. The sensitivity of embryos to other stresses appears to change little during the period of preimplantation development. This has been shown for bovine embryos exposed to hydrogen peroxide [30]. In addition to heat stress, the lack of green forages in the current study has been a challenge for pregnant females. Suboptimal nutritive requirements are a major cause of developmental disability leading to a lower fetal size than its maximal genetic potential [31]. It is well known that sheep is a seasonal breeder that enters estrus in fall and early winter [32]. IUGR has been a common reproductive problem causing pulmonary atresia in sheep fetuses [33]. L-arginine as a supplementary nutrient in the diets of mammals has shown beneficial roles on fetal growth and development due to its activation of nitrous oxide (NO) and polyamines [25]. The reason that the high dose applied in the present study when given at an early stage of gestation reduced neonatal survival at weaning to $50 \%$ is clearly due to that this dose retained interstitial fluids leading to edema in the udder which impeded the natural suckling of offspring. The heaviest lamb birth $(4.99 \mathrm{~kg})$ and weaning $(18.9 \mathrm{~kg})$ weights were obtained from mothers given L-arginine at an early stage of pregnancy $(\mathrm{P}<0.05)$. This lamb heavy weight coincides with the highest level of blood insulin $(\mathrm{P}$ $<0.05)$ and the low level of IGF-I $(\mathrm{P}<0.05)$. A reasonable explanation for the heavy lamb weight accompanied by high maternal insulin might be interpreted from the positive relationship between basal vascular endothelial nitric oxide production and insulin sensitivity [34]. Under physiological circumstances, insulin stimulates arterial vasodilatation in skeletal-muscle vascular beds. By increasing its own delivery and that of glucose to insulin-sensitive tissues, it may amplify its own action in promoting glucose uptake [34], and it has been reported previously [35] that insulin-mediated vasodilatation is impaired in insulin-resistant states. In our study the low arginine increased insulin and decreased IGF-I, whereas the high arginine revealed the opposite (e.g. increased IGF-I and decreased insulin). In a study by Lu et al. [36] on rats, they administered the animals with $100 \mathrm{mg}$ (low) or $200 \mathrm{mg} \mathrm{L-arginine} / \mathrm{kg}$ and found a significant elevation of IGF-I and IGF-II than control. The low dose of our study is still lower than $100 \mathrm{mg}$, which explains the critical effect of the L-arginine level on the metabolic functions. Moreover, the inverse relationship between blood insulin and IGF-I levels accompanied with low survival and low lamb weights at birth and weaning confirms the hypothesis that both the fetal growth and development apparently are dependent on the metabolic actions of insulin, rather than IGF-I. The involvement of IGFs in regulating fetal growth was first reported in clinical studies demonstrating that birth weight is positively correlated with cord blood IGF-I levels [37] [38], and so levels are low in small-for-gestational-age (SGA) infants and are enhanced in large-for-gestational-age babies [39]. The excessive secretion of IGF-I in ewes given the high dose of L-arginine might damage the normal metabolic pathways which seem to be normal in control and L-ewes. Bilby et al. [40] showed a positive relationship between circulating IGF-I and embryonic development, but they didn't mention to what extent of IGF-I elevation this relation is correct. The increase of IGF-I in the late pregnant $\mathrm{H}$-ewes in our study approached as twice that in the same stage in control ewes. Growth hormone trend among gestation stage was not different due to L-arginine. Alterations in the IGF cascade have a role in compromised fetal growth [41]. In ovine gestation, an increase in IGF-I plasma concentrations was associated with increased muscle mass and myofiber hypertrophy [42]. Arginine either at low or high dose when given at an early stage of gestation resulted in decreases of estradiol $17 \beta$ and progesterone $(\mathrm{P}<0.05)$, however, when given at late pregnancy it maintained progesterone as control. Also, low-arginine maintained estradiol as in the control ewes, whereas it reduced $(\mathrm{P}<0.05)$ estradiol in ewes given the high dose of $\mathrm{L}$-arginine. Little research 
has focused on the effects of L-arginine supplementation on progesterone and estradiol. In sheep Saever et al. [43] confirmed that ewes given L-arginine had lower progesterone than control. Additionally, Crane et al. [44] didn't find differences in circulating progesterone due to arginine supplementation.

As far as the gestation stage, our results favored the administration of a low dose of 1 -arginine at an early stage of pregnancy (i.e. starting 21 days postmating) which culminates in the high lamb survival at weaning $(100 \%)$ and the heaviest weight at birth $(4.99 \mathrm{~kg} ;+33.6 \%$ higher than control, $\mathrm{P}<0.05)$ and at weaning $(18.9$ $\mathrm{kg} ;+27.4 \%$ than control, $\mathrm{P}<0.05$ ). This finding was confirmed by Lassala et al. [12] who obtained heavier lamb birth weight in ewes given parenteral arginine by $23 \%$ than control and also $23 \%$ more neonatal survival. Late researchers administered arginine between days 100 - 121 of gestation. Giving arginine in the last 8 weeks of gestation in our study slightly increased birth weight by about $10 \%$, however, when arginine was given at an early pregnancy the increase in lamb birth weight was $20 \%$ than control $(\mathrm{P}<0.05)$. Care must be exercised when using amino acids as supplementary to the pregnant animal diets due to their micro levels in blood circulation. It is preferable to administer a low daily dose of L-arginine ( $75 \mathrm{mg} / \mathrm{kg} \mathrm{B}$.W/56 days) than giving a low or high dose at a late stage of pregnancy in ewes. The reason is that at or around the time of maternal recognition of pregnancy the pregnant uterus might require more amino acids supply for better implantation and placental vascularity. Also, using this regime might rescue the pregnant ewes of suffering from early embryonic losses.

\section{Acknowledgements}

The authors acknowledge the funding of the project No. SR-D-013-2271 provided by Qassim University Scientific Research Deanship (QUSRD), without which this work wouldn't have been appeared.

\section{References}

[1] Gouge, R.C., Marshburn, P., Gordon, B.E., Nunley, W. and Huet-Hudson, Y.M. (1998) Nitric Oxide as a Regulator of Embryonic Development. Biology of Reproduction, 58, 875-879. http://dx.doi.org/10.1095/biolreprod58.4.875

[2] Ignarro, L.J., Buga, G.M., Wei, L.H., Bauer, P.M., Wu, G. and Soldato, P. (2001) Role of the Arginine-Nitric Oxide Pathway in the Regulation of Vascular Smooth Muscle Cell Proliferation. Proceedings of the National Academy of Sciences of the United States of America, 98, 4202-4208. http://dx.doi.org/10.1073/pnas.071054698

[3] Martin, M.J., Jimenez, M.D. and Motilva, V. (2001) New Issues about Nitric Oxide and Its Effects on the Gastrointestinal Tract. Current Pharmaceutical Design, 7, 881-908. http://dx.doi.org/10.2174/1381612013397645

[4] Alderton, W.K., Cooper, C.E. and Knowles, R.G. (2001) Nitric Oxide Synthases: Structure, Function and Inhibition. Journal of Biochemistry, 357, 593-615. http://dx.doi.org/10.1042/bj3570593

[5] Kohli, R., Meininger, C.J., Haynes, T.E., Yan, W., Self, J.T. and Wu, G. (2004) Dietary L-Arginine Supplementation Enhances Endothelial Nitric Oxide Synthesis in Streptozotocin-Induced Diabetic Rats. The Journal of Nutrition, 134, 600-608.

[6] Fu, W.J., Haynes, T.E., Kohli, R., Hu, J., Shi, W., Spencer, T.E., Carroll, R.J., Meininger, C.J. and Wu, G. (2005) Dietary L-Arginine Supplementation Reduces Fat Mass in Zucker Diabetic Fatty Rats. The Journal of Nutrition, 135, $714-$ 721.

[7] Wu, G., Bazer, F.W., Davis, T.A., Kim, S.W., Li, P., Rhoads, J.M., Satterfield, M.C., Smith, S.B., Spencer, T.E. and Yin, Y. (2009) Arginine Metabolism and Nutrition in Growth, Health and Disease. Amino Acids, 37, 153-168. http://dx.doi.org/10.1007/s00726-008-0210-y

[8] Morris Jr., S.M. (2007) Arginine Metabolism: Boundaries of Our Knowledge. The Journal of Nutrition, 137, 1602S1609S.

[9] Rhoads, J.M., Liu, Y., Niu, X., Surendran, S. and Wu, G. (2008) Arginine Stimulates Intestinal Epithelial Cell Migration via a Mechanism Requiring Both Nitric Oxide and P70 ${ }^{\mathrm{s} 6 \mathrm{k}}$ Signaling. The Journal of Nutrition, 138, 1652-1657.

[10] Yao, K., Yin, Y.L., Chu, W.Y., Liu, Z., Deng, D., Li, T., Huang, R., Zhang, J., Tan, B., Wang, W. and Wu, G. (2008) Dietary Arginine Supplementation Increases mTOR Signaling Activity in Skeletal Muscle of Neonatal Pigs. The Journal of Nutrition, 138, 867-872.

[11] Zeng, X., Wang, F., Fan, X., Yang, W., Zhou, B., Li, P., Yin, Y., Wu, G. and Wang, J. (2008) Dietary Arginine Supplementation during Early Pregnancy Enhances Embryonic Survival in Rats. The Journal of Nutrition, 138, 1421-1425.

[12] Lassala, A., Bazer, F.W., Cudd, T.A., Datta, S., Keisler, D.H., Satterfield, M.C., Spencer, T.E. and Wu, G. (2011) Parenteral Administration of L-Arginine Enhances Fetal Survival and Growth in Sheep Carrying Multiple Fetuses. The Journal of Nutrition, 141, 849-855. http://dx.doi.org/10.3945/jn.111.138172 
[13] Mateo, R.D., Wu, G., Bazer, F.W., Park, J.C., Shinzato, I. and Kim, S.W. (2007) Dietary L-Arginine Supplementation Enhances the Reproductive Performance of Gilts. The Journal of Nutrition, 137, 652-656.

[14] National Research Council (NRC) (1985) Nutrient Requirements of Sheep. 6th Edition, National Academy Press, Washington DC.

[15] Clark, P.M.S. and Hales, C.N. (1994) How to Measure Plasma Insulin. Diabetes/Metabolism Reviews, 10, 79-90. http://dx.doi.org/10.1002/dmr.5610100203

[16] Breier, B.H., Gallaher, B.W. and Gluckman, P.D. (1991) Radioimmunoassay for Insulin-Like Growth Factor-I: Solutions to Some Potential Problems and Pitfalls. Journal of Endocrinology, 128, 347-357. http://dx.doi.org/10.1677/joe.0.1280347

[17] Reiter, E.O., Morris, A.H., Macgillivray, M.H. and Weber, D. (1988) Variable Estimates of Serum Growth Hormone Concentrations by Different Radioassay Systems. Journal of Clinical Endocrinology and Metabolism, 66, 68-71. http://dx.doi.org/10.1210/jcem-66-1-68

[18] Joyce, B.G., Read, G.F. and Fahmy, D.R. (1977) A Specific Enzyme-Immunoassay for Progesterone in Plasma. Steroids, 29, 761-770. http://dx.doi.org/10.1016/0039-128X(77)90120-9

[19] Abuknesha, R. and Exley, D. (1978) Design and Development of Oestradiol-17 Enzyme-Immunoassay. In: Pal, S.B. and de Gruyter, W., Eds., Enzyme Labeled Immunoassay of Hormones and Drugs, Berlin, 139-152.

[20] SAS (2000) Statistical Analysis System User's Guide. 8th Edition, SAS Institute, Cary.

[21] Steel, R.G.D. and Torrie, J.H. (1980) Principles and Procedures of Statistics: A Biometrical Approach. 3rd Edition, McGraw-Hill, Inc., New York.

[22] Appleton, J. (2002) Arginine: Clinical Potential of a Semi-Essential Amino. Alternative Medicine Review, 7, $512-522$.

[23] Bazer, F.W., Wu, G., Spencer, T.E., Johnson, G.A., Burghardt, R.C. and Bayless, K. (2010) Novel Pathways for Implantation and Establishment and Maintenance of Pregnancy in Mammals. Molecular Human Reproduction, 16, 135152. http://Dx.Doi.Org/10.1093/Molehr/Gap095

[24] Bazer, F.W., Spencer, T.E., Johnson, G.A. and Burghardt, R.C. (2011) Uterine Receptivity to Implantation of Blastocysts in Mammals. Frontiers Bioscience, S3, 745-767.

[25] Wu, G., Bazer, F.W., Satterfield, M.C., Li, X., Wang, X., Johnson, G.A., Burghardt, R.C., Dai, Z., Wang, J. and Wu, Z. (2013) Impacts of Arginine Nutrition on Embryonic and Fetal Development in Mammals. Amino Acids, 45, 241-256. http://dx.doi.org/10.1007/s00726-013-1515-z

[26] Hansen, P.J. (2009) Effects of Heat Stress on Mammalian Reproduction. Philosophical Transactions of the Royal Society London B: Biological Science, 364, 3341-3350. http://dx.doi.org/10.1098/rstb.2009.0131

[27] Hansen, P.J. (2002) Embryonic Mortality in Cattle from the Embryo's Perspective. Journal of Animal Science, 80, E33-E44.

[28] Dobson, H. and Smith, R.F. (1995) Stress and Reproduction in Farm Animals. Journal of Reproduction and Fertility, S49, 451-461.

[29] Vanroose, G., Nauwynck, H., Soom, A.V., Ysebaert, M.T., Charlier, G., Oostveldt, P.V. and de Kruif, A. (2000) Structural Aspects of the Zona Pellucida of in Vitro-Produced Bovine Embryos: A Scanning Electron and Confocal Laser Scanning Microscopic Study. Biology of Reproduction, 62, 463-469. http://dx.doi.org/10.1095/biolreprod62.2.463

[30] Morales, H., Tilquin, P., Rees, J.F., Massip, A., Dessy, F. and Van Langendonckt, A. (1999) Pyruvate Prevents Peroxide-Induced Injury of in Vitro Preimplantation Bovine Embryos. Molecular Reproduction and Development, 52, 149-157. http://dx.doi.org/10.1002/(SICI)1098-2795(199902)52:2<149::AID-MRD5>3.0.CO;2-4

[31] Gluckman, P., Hanson, M.A., Beedle, A.S., Buklijas, T. and Low, F.M. (2011) Epigenetics of Human Disease. In: Hallgrímsson, B. and Hall, B.K., Eds., Epigenetics: Linking Genotype and Phenotype in Development and Evolution, University of California Press, Berkeley, 398-423.

[32] Dunlap, K.A., Brown, J.D., Keith, A.B. and Satterfield, M.C. (2015) Factors Controlling Nutrient Availability to the Developing Fetus in Ruminants. Journal of Animal Science and Biotechnology, 6, 16-25. http://dx.doi.org/10.1186/s40104-015-0012-5

[33] Orgeig, S., Crittenden, T.A., Marchant, C., McMillan, I.C. and Morrison, J.L. (2010) Intrauterine Growth Restriction Delays Surfactant Protein Maturation in the Sheep Fetus. American Journal of Physiology: Lung Cellular and Molecular Physiology, 298, L575-L583. http://dx.doi.org/10.1152/ajplung.00226.2009

[34] Petrie, J.R., Ueda, S., Webb, D.J., Elliot, H.L. and Connell, J.M.C. (1996) Endothelial Nitric Oxide Production and Insulin Sensitivity: A Physiological Link with Implications for Pathogenesis of Cardiovascular Disease. Circulation, 93, 1331-1333. http://dx.doi.org/10.1161/01.CIR.93.7.1331

[35] Baron, A.D. (1993) 5 Cardiovascular Actions of Insulin in Humans: Implications for Insulin Sensitivity and Vascular 
Tone. Baillière's Clinical Endocrinology and Metabolism, 7, 961-987. http://dx.doi.org/10.1016/S0950-351X(05)80241-1

[36] Lu, Y., Liu, X.M. and Li, S.Q. (2006) Effects of L-Arginine on the Expression of Insulin-Like Growth Factors and Insulin-Like Growth Factor Binding Protein 3 in Rats with Intrauterine Growth Retardation. Chinese Journal of Contemporary Pediatrics, 8, 319-322.

[37] Osorio, M., Torres, J., Moya, F., Pezzullo, J., Salamis, C., Baxter, R., Schwander, J. and Fant, M. (1996) Insulin-Like Growth Factors (IGFs) and IGF Binding Proteins-1, -2, and -3 in Newborn Serum: Relationships to Fetoplacental Growth at Term. Early Human Development, 46, 15-26. http://dx.doi.org/10.1016/0378-3782(96)01737-9

[38] Klauwer, D., Blum, W.F., Hanitsch, S., Rascher, W., Lee, P.D.K. and Kiess, W. (1997) IGF-I, IGF-II, Free IGF-I and IGFBP-1, -2 and -3 Levels in Venous Cord Blood: Relationship to Birth Weight, Length and Gestational Age in Healthy Newborns. Acta Paediatrica, 86, 826-833. http://dx.doi.org/10.1111/j.1651-2227.1997.tb08605.x

[39] Forbes, K. and Westwood, M. (2010) Maternal Growth Factor Regulation of Human Placental Development and Fetal Growth. Journal of Endocrinology, 207, 1-16. http://dx.doi.org/10.1677/JOE-10-0174

[40] Bilby, T.R., Sozzi, A., Lopez, M.M., Silvestre, F.T., Ealy, A.D., Staples, C.R. and Thatcher, W.W. (2006) Pregnancy, Bovine Somatotropin and Dietary N-3 Fatty Acids in Lactating Dairy Cows: I. Ovarian, Conceptus and Growth Hormone-Insulin-Like Growth Factor System Responses. Journal of Dairy Science, 89, 3360-3374. http://dx.doi.org/10.3168/jds.S0022-0302(06)72373-6

[41] Osgerby, J.C., Wathes, D.C., Howard, D. and Gadd, T.S. (2002) The Effect of Maternal Undernutrition on Ovine Fetal Growth. Journal of Endocrinology, 173, 131-141. http://dx.doi.org/10.1677/joe.0.1730131

[42] Li, J., Forhead, A.J., Dauncey, M.J., Gilmour, R.S. and Fowden, A.L. (2002) Control of Growth Hormone Receptor and Insulin-Like Growth Factor-I Expression by Cortisol in Ovine Fetal Skeletal Muscle. Journal of Physiology, 541, 581-589.

[43] Saevre, C., Meyer, A.M., Van Ebon, M.L., Redmer, D.A., Caton, J.S., Kirsch, J.D., Luther, J.S. and Schauer, S.C. (2011) Impacts of Arginine on Ovarian Function and Reproductive Performance at the Time of Maternal Recognition of Pregnancy in Ewes. Sheep Research Report, 52, 13-16.

[44] Crane, A.R., Redden, R.R., Van Emon, M.L., Neville, T.L., Caton, J.S. and Schauer, C.S. (2013) Impacts of Supplemental Arginine on Reproductive Performance in Sheep. Proceedings of Western Section American Society of Animal Science, 64, 154-159. 